\title{
Tipe Urban Spraw/dan Eksistensi Pertanian di Wilayah Pinggiran Kota Denpasar
}

\author{
Putu Indra Christiawan \\ Universitas Pendidikan Ganesha, Singaraja, Indonesia
}

Artikel Masuk : 25 September 2018

Artikel Diterima : 26 Juli 2019

Tersedia Online : 31 Agustus 2019

\begin{abstract}
Abstrak: Kota Denpasar sebagai ibukota Provinsi Bali memiliki daya tarik yang kuat dalam pembangunan wilayah. Keterbatasan ruang wilayah Kota Denpasar mengarahkan perkembangan kota menuju wilayah pinggiran. Perembetan kenampakan fisik perkotaan akan menjadi faktor yang signifikan dalam perkembangan di wilayah pinggiran Kota Denpasar. Penelitian ini bertujuan untuk mengkaji secara keruangan mengenai perkembangan tipe urban sprawl di wilayah pinggiran Kota Denpasar, dan kaitannya dengan eksistensi pertanian. Metode penelitian kualitatif digunakan untuk mengalisis tipe urban sprawl dengan indikator luas penggunaan lahan sawah, taman hutan rakyat (tahura), lahan terbuka dan permukiman. Analisis penginderaan jauh dari keempat indikator tersebut menggunakan sistem informasi geografi (SIG) ditinjau dari tiga seri waktu, yaitu pada tahun 2005, 2010 dan 2015. Pendekatan keruangan digunakan untuk mengkaji pola dan struktur dari tipe urban sprawl. Hasil penelitian menemukan bahwa terdapat dua tipe utama urban sprawl yang berkembang di wilayah pinggiran Kota Denpasar, yaitu leapfrog yang sebagian besar terpencar di bagian utara, dan tipe ribbon terutama yang memusat di bagian timur Kota Denpasar. Kedua tipe urban sprawl tersebut berperan krusial terhadap penurunan jumlah lahan pertanian, terutama sawah, di wilayah pinggiran Kota Denpasar.
\end{abstract}

Kata Kunci: Denpasar; pertanian; urban sprawl; wilayah pinggiran kota

\begin{abstract}
Denpasar City as the capital of Bali Province is attractive to regional development. The limited space of Denpasar City directs the development towards the periphery. The extension of physical urban form will be a significant factor of suburban developments. The study aims to examine the type of urban sprawl development in the Denpasar suburbs, and their relation to the existence of agriculture. The qualitative research method is used to analyze the type of urban sprawl with the following indicators of typical land uses covering rice fields, forest park, open land, and settlements. Remote sensing analysis of these four indicators applies GIS model drawn from three time-series data of 2005, 2010 and 2015. Spatial approaches are applied to examine the patterns and structures of urban sprawl types. The results find two main types of urban sprawl development in the city suburbs, that is, leapfrog type which is mostly scattered in the north, and the ribbon type mainly centered in the eastern part of Denpasar City. Both types of urban sprawl play a crucial role in decreasing the amount of agricultural land, especially rice fields, in the suburbs of Denpasar.
\end{abstract}


Keywords: agriculture; Denpasar; suburbs; urban sprawl

\section{Pendahuluan}

Pertumbuhan perkotaan di Indonesia, terutama di kota-kota besar secara fisik ditandai oleh pertumbuhan yang pesat pada wilayah pinggiran perkotaan (urban fringe) yang dikenal sebagai proses suburbanisasi, yaitu pergeseran fungsi-fungsi kekotaan ke wilayah pinggiran perkotaan membentuk kawasan-kawasan permukiman baru. Suburbanisasi yang terjadi cenderung menjadikan kawasan perkotaan secara fisik meluas secara acak atau terpencar (urban sprawI) dan menjadi semakin tidak terkendali (Mahmud \& Achide, 2012).

Urbanisasi menurut Soetomo (2013) merupakan proses bergesernya masyarakat dari kehidupan perdesaan ke perkotaan. Secara tidak langsung, urbanisasi dapat mengakibatkan pertumbuhan kota, baik yang terkait jumlah penduduk maupun fisik kota (Karakayaci, 2017). Namun, tidak semua pertumbuhan kota sejalan dengan rancangan yang telah disusun. Pertumbuhan perkotaan seringkali terjadi di tengah-tengah wilayah perdesaan yang sebagian besar lahannya berupa lahan pertanian. Pertumbuhan kota yang tidak terencana ini dapat didefinisikan sebagai bentuk dari hasil urban sprawl (Sudhira \& Ramachandra, 2007). Semakin berkembangnya penduduk dan arus urbanisasi yang tinggi menyebabkan urban sprawl, yaitu proses perembetan kenampakan fisik kekotaan ke arah luar (Yunus, 2008).

Menurut Yunus (2008), selain disebabkan oleh peningkatan kebutuhan ruang, urban sprawl juga disebabkan karena adanya perubahan kemampuan sistem transportasi, pembangunan perumahan dan keberadaan infrastruktur. Munculnya kawasan-kawasan perumahan yang tersebar, tidak teratur dan tidak terintegrasi satu sama lain di daerah pinggiran memunculkan ruang-ruang kosong baik antarkawasan perumahan maupun antara kawasan perumahan dan pusat kota (Slaev, Aleksandar, \& Nikiforov, 2013). Hal tersebut menyebabkan tidak efisiennya penyediaan infrastruktur karena mahalnya biaya pengadaan yang tidak sebanding dengan jumlah penggunanya. Oleh karena itu, tidak salah apabila urban sprawl didefinisikan sebagai proses pertumbuhan wilayah pinggiran secara divergen dari inti kota, yaitu pertumbuhan kota yang tidak kompak sehingga menyebabkan sarana dan prasarana kota menjadi tidak efisien. Menurut Almeida (2005), karena tidak adanya sebuah definisi yang universal mengenai urban sprawl, maka pemetaan lahan terbangun merupakan awal yang tepat dalam mengkaji urban sprawl. Peta memberikan gambaran pertumbuhan perkotaan yang mengarah pada wilayah pinggiran kota. Perkembangan perkotaan dapat dipetakan dengan menggunakan data time series untuk membandingkan besarnya urban sprawl pada kurun waktu tertentu.

Kajian tentang urban sprawl mendapat perhatian yang besar di dunia, terutama di negara-negara maju (developed countries). Banyak hasil penelitian menunjukkan bahwa urban sprawl merupakan bagian yang tidak dapat dipisahkan dalam pembangunan dan perkembangan kota-kota besar di dunia (Adaku, 2014; Brueckner, 2000; Heim, 2001; Rusanovskiy, Yashin, Markov, \& Bagautdinova, 2016). Meskipun menjadi perhatian dunia, tetapi kajian tentang urban sprawl sebagai motor penggerak urbanisasi, khususnya urbanisasi sentripetal - proses perubahan suatu wilayah menjadi bersifat kekotaan yang diakibatkan oleh penjalaran sifat-sifat kekotaan dari kota menuju ke wilayah bagian sekitarnya - belum banyak dikaji di negara-negara berkembang (developing countries), terutama pada kota-kota besar di Indonesia. Sebagian besar kajian masih terpusat pada tema besar urbanisasi, tanpa menggali lebih dalam pola dan struktur keruangan yang mengawali proses tersebut. Oleh karenanya, terdapat gap dalam penelitian terkait wilayah kota yang hanya mengkaji dampak urbanisasi, baik dari sisi dampak terhadap iklim (Isima 
et al., 2017), lingkungan biotik (Yule et al., 2015), dan yang paling banyak dikaji adalah dampak terhadap perubahan penggunaan lahan (Gupta, 2014).

Kota Denpasar sebagai salah satu kota besar di Indonesia, dan sekaligus ibukota Provinsi Bali, tidak hanya berfungsi sebagai pusat pemerintahan, tetapi juga pusat perekonomian dan bisnis, pusat kebudayaan dan merupakan pusat pariwisata utama di Pulau Bali. Kondisi ini mendorong dan mempercepat laju pembangunan di Kota Denpasar. Perkembangan wilayah Kota Denpasar selain diakibatkan pembangunan sarana dan prasarana kota, juga dipengaruhi oleh laju migrasi penduduk. Laju migrasi penduduk yang dimaksud adalah migrasi penduduk dari perdesaan menuju ke wilayah perkotaan. Hal ini juga didukung oleh pendapat Muta'ali (2013) yang menyatakan bahwa Pulau Bali merupakan wilayah yang menjadi salah satu konsentrasi sumber daya ekonomi di Indonesia, sehingga menyebabkan penduduk juga terkonsentrasi di wilayah tersebut. Tingginya laju migrasi di daerah perkotaan, terutama menuju Kota Denpasar sebagai jantung ibukota provinsi menjadi bukti bahwa Kota Denpasar memang diminati oleh para kaum migran. Kondisi ini dibuktikan dari jumlah penduduk Kota Denpasar sampai akhir tahun 2017 sebesar 833.900 jiwa, dan dari jumlah tersebut 415.417 jiwa adalah penduduk migran (BPS Kota Denpasar, 2017). Data tersebut menjelaskan bahwa hampir 50\% jumlah penduduk Kota Denpasar dipenuhi kaum migran.

Padatnya jumlah penduduk ini dikhawatirkan akan memberikan beban yang sangat berat bagi Kota Denpasar lantaran dengan luas wilayah kota yang hanya sebesar 127,88 $\mathrm{km}^{2}$, sejatinya daya tampung ideal Kota Denpasar hanya 200.000 sampai dengan 250.000 penduduk. Pertambahan penduduk di wilayah perkotaan yang semakin meningkat mengakibatkan peningkatan kebutuhan terhadap ruang bertambah sedangkan ruang tetap luasnya, maka terjadi suatu perkembangan ke daerah kawasan pinggiran dari kota yang bertujuan memberikan pemenuhan ruang bagi penduduk yang semakin meningkat jumlahnya. Implikasi dari kepadatan jumlah penduduk di Kota Denpasar ini adalah mendorong adanya perembetan pembangunan permukiman, infrastruktur dan utilitas kota ke arah wilayah pinggiran Kota Denpasar. Wilayah pinggiran Kota Denpasar yang dimaksud adalah wilayah yang bersifat peri-urban yang masih terdapat di dalam wilayah administrasi Kota Denpasar, maupun wilayah-wilayah yang berbatasan langsung dengan Kota Denpasar.

Penelitian ini bertujuan untuk mengkaji secara keruangan mengenai perkembangan tipe urban sprawl di wilayah pinggiran Kota Denpasar, dan kaitannya dengan eksistensi pertanian. Penelitian ini bersifat urgen, karena selama ini penelitian sejenis hanya berfokus pada faktor determinan yang menyebabkan urban sprawl (Karakayaci, 2017; Queslati, Alvanides, \& Garrod, 2015; Slaev et al., 2013) dan dampak dari urbanisasi (Dubey \& Kumar, 2013; Mahmud \& Achide, 2012; Yule et al., 2015), sehingga belum menyentuh akar rumput dari gejala yang mengakomodasi urbanisasi masuk ke wilayah pinggiran kota. Belum banyak penelitian yang mengkaji dan mengungkapkan secara spasial tipe urban sprawl, khususnya yang menjalar di wilayah pinggiran kota. Oleh karena itu, pengkajian tipe urban sprawl dalam penelitian ini akan melengkapi studi tentang urban sprawl. Penelitian ini diperlukan untuk menentukan langkah atau kebijakan untuk penataan wilayah perkotaan secara komprehensif dan berjangka panjang. Berdasarkan kebutuhan tersebut, maka dipandang penting untuk mengkaji tipe urban sprawl pada wilayah pinggiran Kota Denpasar.

\section{Metode Penelitian}

Kajian ini menggunakan metode penelitian kualitatif, khususnya metode survei deskriptif. Aplikasi metode survei deskriptif dalam penelitian ini adalah dengan menginterpretasikan data dengan mengikuti klasifikasi umum yang berlaku, yaitu menelaah 
tipe-tipe urban sparwl. Penilaian terhadap tipe urban sprawl dalam penelitian ini merujuk pada perubahan penggunaan lahan dengan empat indikator, yaitu (1) sawah, (2) taman hutan raya (tahura), (3) lahan terbuka dan (4) permukiman. Analisis penginderaan jauh (remote sensing) dari keempat indikator tersebut menggunakan Sistem Informasi Geografis (SIG) dengan perangkat lunak ArcGIS ditinjau dari tiga seri waktu, yaitu pada tahun 2005, 2010 dan 2015 yang bersumber dari Citra ALOS AVNIR-2, Peta RBI Lembar Kota Denpasar dan Peta Administrasi Kota Denpasar.

Lokasi penelitian berfokus pada wilayah pinggiran di empat kecamatan di Kota Denpasar yang masih berada dalam batas administrasi kota. Objek dalam kajian adalah tipe urban sprawl. Tahapan penelitian diawali dengan pengumpulan data perubahan penggunaan lahan dengan teknik observasi melalui citra satelit. Selanjutnya data dianalisis ini dengan analisis penginderaan jauh untuk memberikan nilai pada masing-masing indikator perubahan penggunaan lahan. Lebih lanjut, proses analisis data tipe urban sprawl dilakukan dengan mengklasifikasikan perkembangan perubahan penggunaan lahan berdasarkan atribut fisik luas lahan permukiman, sementara analisis data eksistensi lahan pertanian ditinjau dari perubahan luas sawah, tahura dan lahan terbuka dari tiga seri waktu. Hasil analisis kemudian diinterpretasi dengan teknik deskriptif kualitatif menggunakan pendekatan spasial untuk mengkaji pola dan struktur dari tipe urban sprawl yang berkembang di wilayah pinggiran Kota Denpasar.

\section{Hasil dan Pembahasan}

Ekspansi dari kenampakan fisik perkotaan adalah fenomena umum yang menyebar di wilayah Kota Denpasar. Dewasa ini, penyebaran kenampakan fisik perkotaan tersebut tidak hanya mengarah ke arah dalam atau pusat kota, tetapi lebih cepat dan masif ke bagian luar atau pada wilayah pinggiran Kota Denpasar. Penyebaran ini terutama mengarah pada wilayah pinggiran kota yang berada tidak jauh dari wilayah inti kota (Dubey \& Kumar, 2013). Berbagai studi menunjukkan berbagai faktor yang mendorong ekspansi perkotaan mengarah ke wilayah pinggiran kota. Pontoh \& Kustiawan (2009) menjabarkan empat faktor penyebab proses urban sprawl. Pertama, kebijakan perencanaan dari pemerintah, terutama kebijakan pembangunan transportasi dan perumahan, meliputi (1) pembangunan jalan besar antarkota sehingga mendorong munculnya lokasi permukiman baru dan (2) pemberian subsidi bagi perumahan yang tidak memandang lokasi sehingga banyak real estat dibangun secara lompat katak. Kedua, spekulasi tanah karena pengaruh pembangunan leapfrog dilakukan dengan menunggu harga tanah naik terlebih dahulu baru mulai melakukan pembangunan. Ketiga, peraturan guna lahan yang ketat di kota sehingga mengundang para investor mencari tanah di luar kota. Terakhir, akibat perhitungan beban biaya layanan fasilitas kota yang mahal.

Polidoro, de Lollo, \& Barros (2012) menambahkan bahwa pertumbuhan penduduk, peningkatan pendapatan rumah tangga, subsidi investasi infrastruktur seperti jalan, pemanfaatan lahan yang tidak efektif, pertumbuhan berlebihan, masalah sosial di kota-kota pusat dan kebijakan pertanahan dianggap penyebab utama urban sprawl di wilayah pinggiran kota. Paralel dengan pandangan sebelumnya, Jain, Dimri, \& Niyogi (2016) mengemukakan bahwa wilayah pinggiran kota yang memiliki kepadatan penduduk yang lebih rendah daripada inti kota rentan terhadap urban sprawl. Urban sprawl juga mengarah pada pola penggunaan lahan yang tidak menguntungkan bagi pengembangan model permukiman berkelanjutan dan karenanya, meningkatkan keberadaan permukiman kumuh dan permukiman liar yang pada gilirannya akan mengancam eksistensi pertanian di wilayah pinggiran kota (Mujiandari, 2014)

Pada kasus wilayah pinggiran Kota Denpasar, terdapat dua tipe urban sprawl yang memicu perubahan tata guna lahan. Perubahan tata guna lahan wilayah pinggiran Kota 
Denpasar sebagai manifestasi perkembangan urban sprawl seperti terlihat pada Gambar 1. Hasil penelitian menunjukkan bahwa lahan pertanian di wilayah pinggiran Kota Denpasar mengalami penurunan. Penurunan luas lahan pertanian di wilayah pinggiran Kota Denpasar seperti terlihat pada Tabel 1.

Tabel 1. Penurunan Luas Lahan Pertanian di Wilayah Pinggiran Kota Denpasar

\begin{tabular}{clccrr}
\hline No & Lahan Pertanian & $\mathbf{2 0 0 5}\left(\mathbf{m}^{\mathbf{2}}\right)$ & $\mathbf{2 0 1 0}\left(\mathbf{m}^{\mathbf{2}}\right)$ & $\mathbf{2 0 1 5}\left(\mathbf{m}^{\mathbf{2}}\right)$ & $\begin{array}{c}\text { Penurunan } \\
\mathbf{2 0 0 5 - 2 0 1 5}\left(\mathbf{m}^{\mathbf{2}}\right)\end{array}$ \\
\hline 1 & Sawah & $26.122 .222,05$ & $23.430 .936,66$ & $22.540 .468,60$ & $3.581 .753,45$ \\
2 & Tahura & $25.991 .766,62$ & $25.530 .300,33$ & $25.259 .205,10$ & $732.561,52$ \\
3 & Lahan terbuka hijau & $6.432 .537,12$ & $6.432 .537,12$ & $6.401 .538,07$ & $30.999,05$ \\
\hline \multicolumn{2}{l}{ Sumber: Analisis Penulis, 2018 } & &
\end{tabular}

Pada Tabel 1 terlihat bahwa sawah merupakan jenis lahan pertanian yang secara konsisten mengalami penurunan, dan penurunan paling dramatis terjadi dari tahun 2005 sampai dengan tahun 2010, yaitu sebesar 10,3\% lahan sawah hilang. Sawah dan lahan pertanian lainnya yang hilang beralih fungsi menjadi permukiman. Secara periodik, permukiman mengalami perluasan dari tahun 2005 sebesar $61.918 .900,70 \mathrm{~m}^{2}$ menjadi $64.692 .219,99 \mathrm{~m}^{2}$ pada tahun 2010 , dan menyentuh angka $65.802 .648,50 \mathrm{~m}^{2}$ pada tahun 2015.

Tipe urban sprawl yang berperan dalam menciptakan lahan terbangun (built-up area) pada lahan pertahian di wilayah pinggiran Kota Denpasar dapat dikelompokkan menjadi tipe lompat katak (leapfrog development) dan tipe linier (ribbon development). Urban sprawl tipe leapfrog ditunjukkan dengan ekspresi keruangan lahan terbangun yang terpencar, sementara tipe ribbon development ditandai dengan permukiman yang memusat di sepanjang jalan.

\section{Urban Sprawl Tipe Leapfrog}

Leapfrog merupakan tipe urban sprawlyang berkembang secara sporadis. Fenomena ini sangat dipengaruhi oleh inisiatif pengembang dan juga dipengaruhi oleh faktor individu pemilik lahan. Pola dari tipe leapfrog ini terjadi ketika pengembang membangun permukiman melompat dari satu area ke area lain (Ngoran \& Xue, 2015). Urban sprawl tipe leapfrog ini bertanggung-jawab terhadap akselerasi perubahan ekspresi keruangan wilayah pinggiran kota karena secara ofensif menekan lahan-lahan pertanian yang berada di sekitar permukiman tersebut untuk 'bergabung' dan berubah menjadi lahan terbangun (Daneshopur \& Shakibamanesh, 2011).

Perkembangan lahan terbangun (built-up area) di wilayah pinggiran Kota Denpasar yang berlangsung secara melompat (leapfrog) tersebar terutama di Kecamatan Denpasar Utara. Gejala urban sprawl tipe ini sangat mencolok dilihat dari perkembangannya pada citra Google Earth seperti terlihat pada Gambar 2 (a). Fenomena ini memiliki empat gejala utama, yaitu (1) pembangunan permukiman tidak terjadi secara terpusat pada satu lokasi, tetapi tersebar di berbagai lokasi di wilayah pinggiran kota, (2) leapfrog meninggalkan lahan-lahan pertanian yang luas sebagai ruang yang mengisi kekosongan di antara lahan terbangun, dan (3) leapfrog berkembang sebagai konsekuensi atas pembangunan sebelumnya, dan (4) leapfrog berfungsi sebagai 'jembatan penghubung' (patchwork) bagi pembangunan-pembangunan selanjutnya di wilayah pinggiran kota. Perkembangan lahan terbangun dengan tipe leapfrog di Kecamatan Denpasar Utara mengindikasikan adanya interaksi antara Kota Denpasar dan hinterland yang berada di luar batas administrasi kota. Interaksi ini secara tidak langsung akan mendorong urban sprawl menuju wilayah perdesaan di luar wilayah Kota Denpasar. 


\section{Tipe Urban Sprawl dan Eksistensi Pertanian di Wilayah Pinggiran Kota Denpasar}

Salah satu daerah perbatasan Kota Denpasar, khususnya dengan Kecamatan Denpasar Utara yang menjadi sasaran interaksi tersebut adalah Desa Batubulan, Kecamatan Sukawati, Kabupaten Gianyar yang pada awalnya merupakan sebuah desa dengan dominasi sektor pertanian sebagai penggerak perekonomian. Menurut Laporan Statistik Pertanian Kecamatan Sukawati tahun 2016, terjadi penyusutan luas lahan produktifnya dan penurunan jumlah penduduk yang bermatapencaharian petani mendominasi sebanyak 77\%. Di wilayah lain di Kabupaten Gianyar, terjadi pertumbuhan alih fungsi lahan pertanian menjadi nonpertanian yang pesat di Desa Batubulan dari tahun 1964 hingga tahun 2016 dengan rata-rata penyusutan 14,03 Ha per tahun (Rupini, Dewi, \& Sueca, 2017).

Kebutuhan ekonomi masyarakat agraris yang mendesak, dan tawaran harga yang sangat tinggi dari pengembang mengakibatkan pemilik lahan tidak memiliki banyak pilihan. Mayoritas petani menjual lahan untuk memenuhi kebutuhan dan gaya hidup yang telah mengarah pada sifat perkotaan. Di sisi lain, banyak sawah masyarakat petani yang sudah 'terkepung' oleh lahan terbangun, sehingga kondisi ini juga mendesak petani untuk ikut juga menjual lahan pertanian mereka. Kondisi ini merupakan jalan masuk bagi pengembang dalam mengubah struktur keruangan wilayah pinggiran kota menjadi lahan terbangun. Implikasi dari perkembangan urban sparwl tipe leap-frog ini adalah akan mengubah lahan pertanian di wilayah pinggiran kota menjadi lahan terbangun secara gradual dan masif. Perkembangan tipe leap-frog merupakan tantangan utama dalam perencanaan wilayah, khususnya perkotaan, karena arah dan bentuk perkembangan sifat fisik perkotaan yang menjalar ke wilayah pinggiran kota secara lompat katak ini tidak dapat diprediksi dan menjadi link yang tidak terputus dalam urbanisasi di wilayah pinggiran kota. Dengan kata lain tipe leap-frog merupakan tiper urban sprawl yang bekerja secara domino effect dalam mengubah kenampakan fisik wilayah pinggiran kota. Gejala urban sprawl tipe leap-frog dapat dilihat dari pembangunan tunggal yang dikelilingi oleh lahan-lahan luas yang masih berorientasi pertanian seperti terlihat pada Gambar 2 (b).

Alih fungsi lahan adalah perubahan fungsi sebagian atau seluruh kawasan lahan dari fungsinya semula seperti yang direncanakan menjadi fungsi lain yang berdampak negatif terhadap lingkungan dan potensi lahan itu sendiri. Fenomena yang tidak jauh berbeda di kota-kota besar Indonesia lainnya. Konversi lahan pertanian merupakan fenomena yang tidak dapat dihindari bagi kota-kota besar seperti hasil penelitian di Kota Semarang. Kota Semarang merupakan kota besar sekaligus menjadi ibukota Provinsi Jawa Tengah. Oleh karena itu, Kota Semarang menjadi tujuan urbanisasi kota-kota di sekitarnya. Hal ini mendesak terjadinya proses alih fungsi lahan pada area pinggiran Kota Semarang dari pertanian ke nonpertanian (Dewi \& Rudiarto, 2013).

Hasil kajian ini hampir sama dengan penelitian Astuti (2011) yang menyatakan bahwa tren laju konversi lahan di Kecamatan Cisarua tahun 2001-2010 terus mengalami peningkatan. Konversi lahan pertanian di Kecamatan Cisarua tertinggi terjadi pada tahun 2006, karena ada pertambahan jumlah objek wisata dan jumlah penduduk. Tingkat konversi lahan untuk pertanian dan permukiman masing-masing sebesar 2,28\% dan 3,94\%. Faktor-faktor yang mempengaruhi penduduk pada tingkat rumah tangga dalam mengonversi lahan adalah harga lahan, jumlah tanggungan, pendapatan, dan luas lahan yang dimiliki saat sebelum menjual. Harga lahan di tingkat Kecamatan Cisarua pada tahun 2001-2010 berkorelasi positif dengan konversi lahan. Laju konversi semakin tinggi karena kenaikan harga lahan di Kecamatan Cisarua lebih murah dibandingkan dengan daerah asal mayoritas investor. 


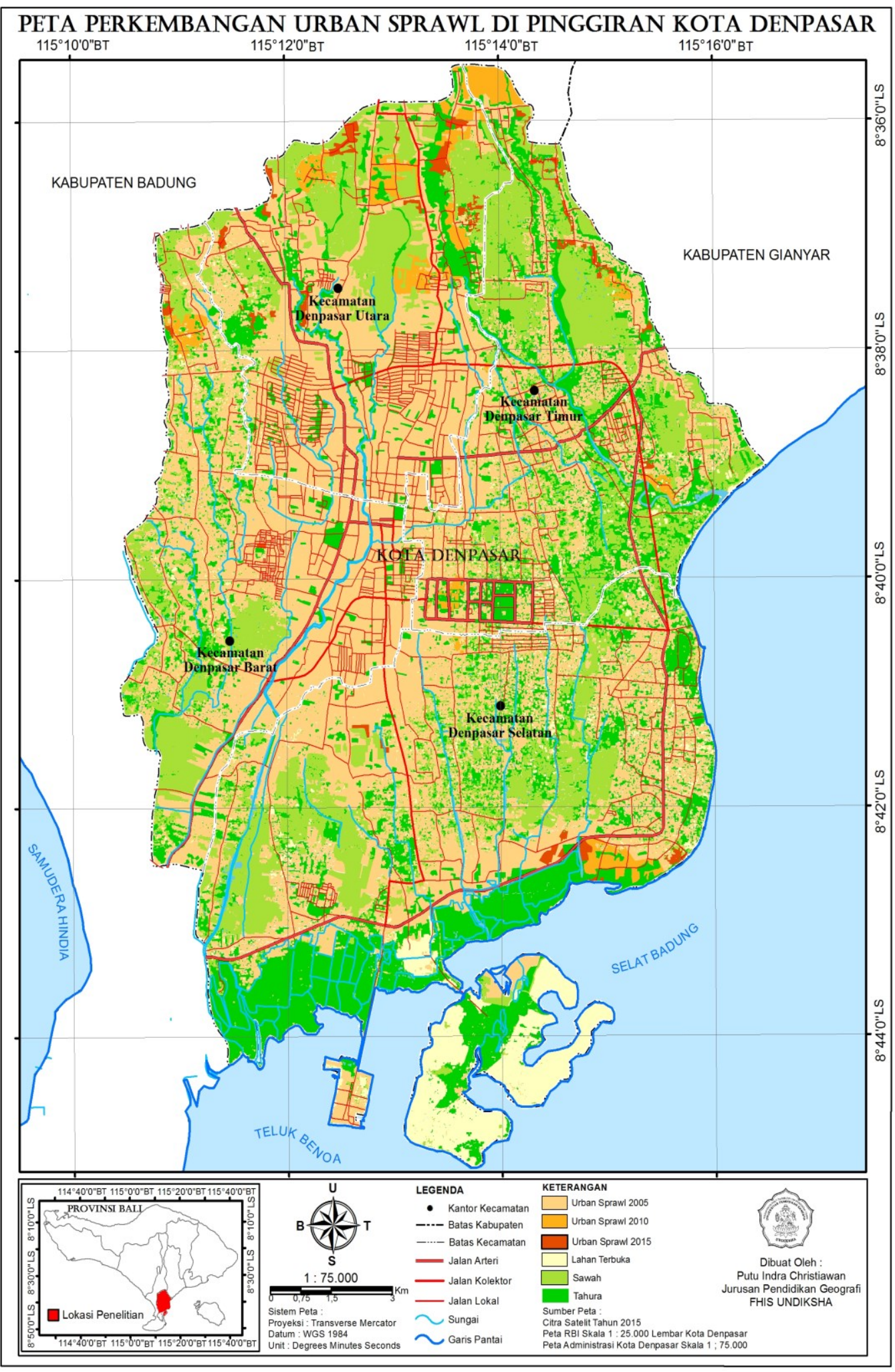

Gambar 1. Peta Perkembangan Urban Spraw/di Wilayah Pingiran Kota Denpasar 


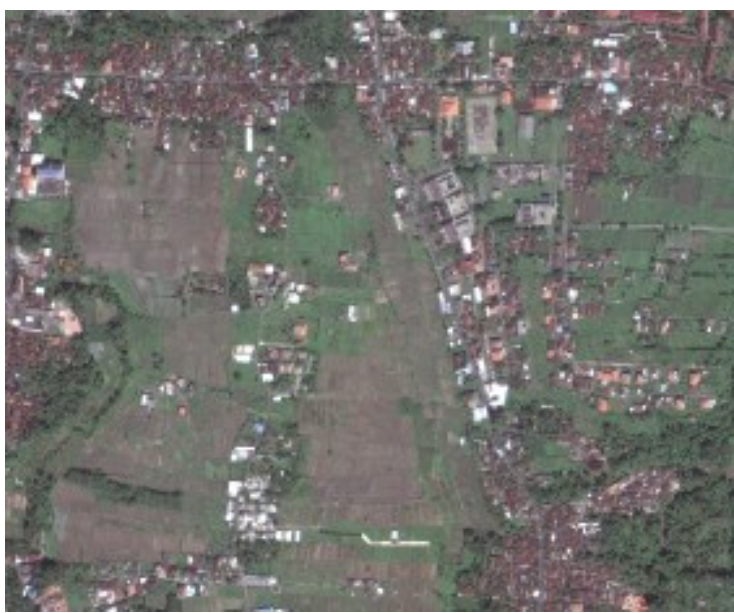

(a)

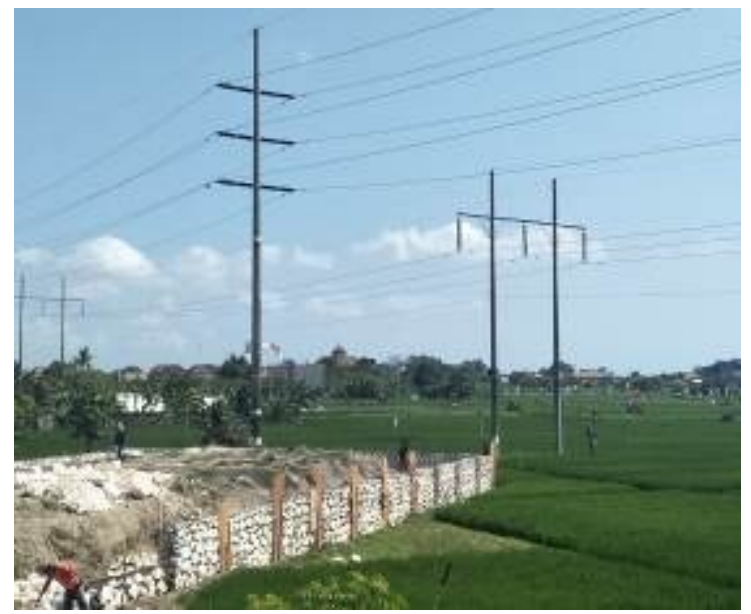

(b)

\section{Gambar 2. (a) Citra Google Earth Leapfrog Development; dan (b) Perubahan Tata Guna Lahan di Kecamatan Denpasar Utara}

\section{Urban Sprawl Tipe Ribbon Development}

Ribbon development merupakan tipe urban sprawl yang berkembang mengikuti koridor-koridor transportasi utama (Giyarsih, 2017). Fenomena ini sangat dipengaruhi oleh nilai strategis dari keberadaan jalan sebagai prasarana transportasi yang telah dibangun di wilayah pinggiran kota. Pola dari tipe ribbon development ini terjadi pada lahan-lahan pertanian yang dilalui dan memiliki akses langsung terhadap jalan. Jalan dalam urban sprawl tipe ribbon development merupakan media perantara yang mampu meningkatkan nilai ekonomis lahan pertanian di wilayah pinggiran kota (Verbeek, Boussauw, \& Pisman, 2014). Ribbon development ini memicu percepatan perubahan ekspresi keruangan wilayah pinggiran kota secara linier di sepanjang jalan.

Perkembangan lahan terbangun (built-up area) di wilayah pinggiran Kota Denpasar yang berlangsung secara linier tersebar terutama di wilayah pinggiran Kecamatan Denpasar Timur. Gejala tipe ribbon development ini merupakan penciri utama dari perkembangan urban sprawl di bagian timur dari Kecamatan Denpasar Timur, yang terlihat jelas pada citra Google Earth seperti terlihat pada Gambar 3 (a). Fenomena ini memiliki empat gejala utama, yaitu (1) pembangunan permukiman terjadi secara terpusat di sepanjang jalan utama, (2) ribbon development secara masif dan penuh mengubah lahan pertanian di sepanjang jalan menjadi lahan terbangun, (3) ribbon development berkembang sebagai konsekuensi atas adanya pembangunan infrastruktur jalan, dan (4) tipe ini berfungsi sebagai pembangkit nilai ekonomis lahan-lahan pertanian di wilayah pinggiran kota. Perkembangan lahan terbangun dengan tipe ribbon development di Kecamatan Denpasar Timur mengindikasikan adanya pertumbuhan ekonomi yang tinggi, yang ditengarai akibat dari pembangunan pusat-pusat pertokoan dan jalur distribusi perdagangan.

Penawaran lahan pertanian di wilayah pinggiran kota dengan harga yang tinggi tidak terlepas dari ketersediaan aksesibilitas (Bytyqi, 2018). Jalan merupakan prasarana transportasi yang dibutuhkan masyarakat pinggiran kota untuk memasarkan produk pertanian ke luar desa, sehingga kualitas dan kuantitas jalan yang dibangun harus memliki standar yang baik. Pembangunan prasarana jalan yang baik tidak hanya memberikan peluang bagi masyarakat petani, tetapi merupakan pintu masuk bagi penduduk perkotaan dan berbagai fungsi kota masuk dan mengubah ekspresi keruangan wilayah pinggiran kota. Dengan kata lain, keberadaan jalan akan mendorong adanya pembangunan di sepanjang 
jalan, sehingga lahan pertanian yang berada di pinggir jalan akan menjadi lahan pertanian pertama yang akan berubah fungsi. Pembangunan jalan mendorong terjadinya urban sprawl dengan tipe ribbon development seperti terlihat pada Gambar 3 (b).

Keberadaan jalan sebagai syarat aksesibilitas membuka berbagai peluang bisnis di wilayah pinggiran Kota Denpasar. Salah satu peluang bisnis yang paling menjanjikan adalah pembangunan perumahan untuk memenuhi kebutuhan penduduk perkotaan yang memilih bermukim di luar wilayah pusat kota. Sejalan dengan pembangunan permukiman, berbagai usaha perdagangan juga secara langsung akan memadati kawasan permukiman tersebut. Dewi \& Sarjana (2015) menyatakan bahwa kebutuhan lahan untuk kegiatan bisnis perdagangan didapatkan dengan mengorbankan sebagian lahan pertanian di Kota Denpasar. Implikasi utama dari urban sprawl tipe ribbon development ini adalah mendorong pemilik lahan pertanian di wilayah pinggiran kota ini untuk cara menjual lahannya untuk usaha bisnis (pengkavelingan), sehingga menciptakan pembangunan yang seragam dalam bentuk pertokoan maupun pusat bisnis lain. Kecenderungan lain dari tipe ribbon development ini adalah penciptaan bangkitan-bangkitan pergerakan yang baru di wilayah pinggiran kota. Penelitian Boussauw, Derudder, \& Witlox (2011) menunjukkan bahwa keberadaan pembangunan yang masif di sepanjang jalan mengakibatkan kepadatan yang mengarah pada kemacetan lalu lintas, dan kondisi ini juga memperkuat daya dorong migrasi penduduk perdesaan, terutama angkatan tenaga kerja menuju ke kota (Queslati et al., 2015).

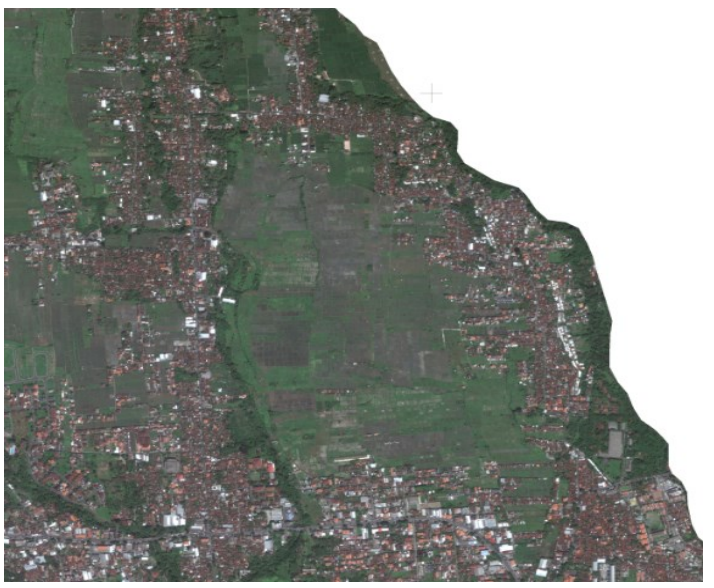

(a)

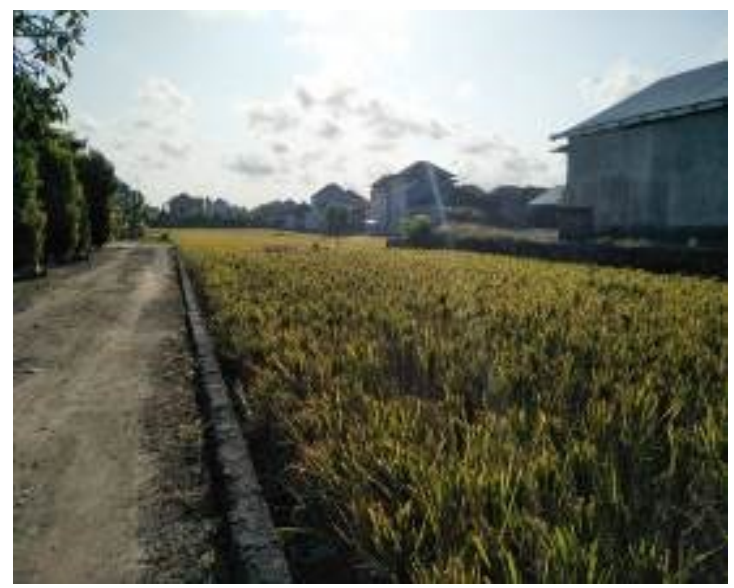

(b)

\section{Gambar 3. (a) Citra Google Earth Ribbon Development; dan (b) Pembangunan Jalan pada Areal Pertanian di Kecamatan Denpasar Timur}

\section{Kesimpulan}

Kajian mengenai tipe urban sprawl yang berlangsung di wilayah pinggiran kota menunjukkan bahwa secara perlahan eksistensi pertanian semakin berkurang. Eksistensi pertanian secara gradual mengalami pengurangan secara kuantitatif akibat adanya pengaruh urban sprawl yang berlangsung dengan tipe leapfrog dan tipe ribbon development. Tipe leapfrog mengubah lahan pertanian secara acak dan dalam skala yang tidak terlalu besar, akan tetapi secara konsisten mengubah satu per satu fungsi tata guna lahan pertanian menjadi lahan terbangun. Sementara itu, urban sprawl tipe ribbon development akan mengurangi luas lahan pertanian secara drastis, terutama lahan 


\section{Tipe Urban Sprawl dan Eksistensi Pertanian di Wilayah Pinggiran Kota Denpasar}

pertanian yang berada di sepanjang jalan yang telah dibangun. Mengingat lahan di sepanjang jalan memiliki nilai aksesibilitas dan nilai ekonomis yang sangat tinggi. Di sisi lain, dapat disimpulkan bahwa alih fungsi lahan pertanian dengan tipe leap-frog digerakkan oleh pengembang perumahan, sementara tipe ribbon development dimotori oleh pebisnis yang akan mengubah fungsi tata guna lahan pertanian menjadi pusat ekonomi atau perdagangan. Penelitian ini menunjukkan adanya variasi tipe urban sprawl yang menjalar di wilayah pinggiran kota, dan penelitian lanjutan dibutuhkan untuk mendesain model interaksi desa-kota yang berkelanjutan, sehingga penurunan luas lahan pertanian akibat tipe urban sparwl yang menjalar ke wilayah pinggiran kota dapat diminimalisir, dan sebaliknya urbanisasi dapat disinergikan untuk menunjang pengembangan wilayah pinggiran kota sesuai dengan potensi fisik, sosial, ekonomi dan budaya yang dimilikinya.

\section{Daftar Pustaka}

Adaku, E. (2014). Urban Sprawl: A view from developing and developed Countries. African Journal of Geography and Regional Planning, 1(6), 193-207.

Almeida, B. (2005). A GIS Assessment of Urban Sprawl in Richmond, Virginia. Blacksburg. Virginia Polytechnic Institute and State University.

Astuti, D. I. (2011). Keterkaitan harga lahan terhadap laju konversi lahan pertanian di Hulu Sungai Ciliwing Kabupaten Bogor. Institut Pertanian Bogor.

Boussauw, K., Derudder, B., \& Witlox, F. (2011). Measuring spatial separation pro-cesses through the minimum commute: The case of Flanders. European Journalof Transport and Infrastructure Resea, 11(1), 42-60.

Badan Pusat Statistik (BPS) Kota Denpasar. (2017). Kota Denpasar dalam angka 2017.

Brueckner, J. (2000). Urban sprawl: Diagnosis and remedies. International Regional Science Review, 23, 160171.

Bytyqi, V. (2018). The impacts of settlement extension on soil resources: A case study in drenica river basin (Kosovo ). Media Komunikasi Geografi, 19(1), 101-113.

Daneshopur, A., \& Shakibamanesh, A. (2011). Compact city dose it create an obligatory context for urban sustainability? International Journal of Architectural Engineering and Urban Planning, 21(1), 110-117.

Dewi, I. A. L., \& Sarjana, I. M. (2015). Faktor-faktor pendorong alihfungsi lahan sawah menjadi lahan nonpertanian (Kasus Subak Kerdung, Kecamatan Denpasar Selatan). Jurnal Manajemen Agribisnis, 3(2), 163171.

Dewi, N. K., \& Rudiarto, I. (2013). Identifikasi alih fungsi lahan pertanian dan kondisi sosial ekonomi masyarakat daerah pinggiran di Kecamatan Gunungpati Kota Semarang. Jurnal Wilayah dan Lingkungan, 1(2), 175188. doi:10.14710/jwl.1.2.175-188.

Dubey, P., \& Kumar, D. (2013). Urban sprawl and its impact on urban environment. IOSR Journal of Mechanical and Civil Engineering, 9(5), 26-31.

Giyarsih, S. R. (2017). Regional management of areas with indications of urban sprawl in the surrounding areas of Universitas Muhammadiyah, Yogyakarta , Indonesia. Indonesian Journal of Geography, 49(1), 35-41. doi:10.22146/ijg.16842.

Gupta, R. (2014). The pattern of urban land-use changes : A case study of the indian cities. Environment and Urbanization Asia, 5(1), 83-104. doi:10.1177/0975425314521539.

Heim, C. E. (2001). Leapfrogging, urban sprawl, and growth management: Phoenix, 1950-2000. The American Journal of Economics and Sociology, 60(1), 245-255.

Isima, K., Chan, A., Justina, K., Morris, K., Ooi, M. C. G., Oozeer, M. Y., ... Al-qrimli, H. F. (2017). Impact of urbanization level on the interactions of urban area, the urban climate, and human thermal comfort. Applied Geography, 79, 50-72. doi:10.1016/j.apgeog.2016.12.007.

Jain, M., Dimri, A., \& Niyogi, D. (2016). Urban sprawl patterns and processes in Delhi from 1977 to 2014 based on remote sensing and spatial metrics approaches. Earth Interactions, 20(14), 1-29. doi:10.1175/EI-D15-0040.1. 
Karakayaci, Z. (2017). The concept of urban sprawl and its causes. The Journal of International Social Research, 9(45), 815-818. doi:10.17719/jisr.20164520658.

Mahmud, A., \& Achide, A. S. (2012). Analysis of land use/land cover changes to monitor urban sprawl in keffinigeria. Environmental Research Journal, 6(2), 130-135.

Mujiandari, R. (2014). Perkembangan urban sprawl Kota Semarang pada wilayah Kabupaten Demak tahun 2001-2012. Jurnal Wilayah dan Lingkungan, 2(2), 129-142. doi:10.14710/jwl.2.2.129-142.

Muta'ali, L. (2013). Pengembangan wilayah perdesaan. Yogyakarta: Badan Penerbit Fakultas Geografi (BPFG) Universitas Gadjah Mada.

Ngoran, D. S., \& Xue, X. (2015). Addressing urban sprawl in Douala, Cameroon: Lessons from Xiamen integrated coastal management. Journal of Urban Management, 4(1), 53-72. doi:10.1016/j.jum.2015.05.001.

Polidoro, M., Lollo, J. A. de, \& Barros, M. V. F. (2012). Urban sprawl and the challenges for urban planning. Journal of Environmental Protection, 3(9), 1010-1019. doi:10.4236/jep.2012.39117.

Pontoh, N. K., \& Kustiawan, I. (2009). Pengantar perencanaan perkotaan. Bandung: Penerbit ITB.

Queslati, W., Alvanides, S., \& Garrod, G. (2015). Determinants of urban sprawl in European Cities. Urban Studies, 52(9), 1594-1614.

Rupini, A. A. A. D., Dewi, N. K. A., \& Sueca, N. P. (2017). Implikasi alih fungsi lahan pertanian pada perkembangan spasial daerah pinggiran kota (studi kasus: Desa Batubulan, Gianyar). Jurnal Ilmiah Arsitektur, 5(2), 9-18.

Rusanovskiy, V., Yashin, N. ., Markov, V., \& Bagautdinova, N. . (2016). Evolution of the spatial models of the economic growth in the analysis of urbanization in Russian Regions. International Business Management, 19(21), 5093-5100.

Slaev, Aleksandar, D., \& Nikiforov, I. (2013). Factors of urban sprawl in Bulgaria. SPATIUM International Review, 29, 22-29.

Soetomo, S. (2013). Urbanisasi dan Morfologi, Proses perkembangan peradaban \& wadah ruang: Menuju ruang kehidupan yang manusiawi. Yogyakarta: Graha Ilmu.

Sudhira, H. ., \& Ramachandra, T. . (2007). Characterising urban sprawl from remote sensing data and using landscape metrics. In 10th International Conference on Computers in Urban Planning and Urban Management. Brazil: Iguassu Falls.

Verbeek, T., Boussauw, K., \& Pisman, A. (2014). Presence and trends of linear sprawl: Explaining ribbon development in the north of Belgium landscape and urban planning presence and trends of linear sprawl: Explaining ribbon development in the north of Belgium. Landscape and Urban Planning, 128, 48-59. doi:10.1016/j.landurbplan.2014.04.022.

Yule, C. M., Gan, J. Y., Jinggut, T., Lee, K. V., Yule, C. M., Gan, J. Y., Lee, K. V. (2015). Urbanization affects food webs and leaf-litter decomposition in a tropical stream in Malaysia. Freshwater Science, 34(2), 702715. doi:10.1086/681252.

Yunus, H. S. (2008). Dinamika wilayah peri-urban determinan masa depan kota. Yogyakarta: Pustaka Pelajar. 